\title{
Fulfilling Energy Demand in Skyscraper Through Photovoltaic Cell (Pv)
}

\author{
Leena Shende ${ }^{1}$, Dr. Arif khan ${ }^{2}$ \\ ${ }^{I}$ Mtech student, ${ }^{2}$ principal \\ NCET, Nagpur, India
}

DOI: 10.46335/IJIES.2020.5.11.6

\begin{abstract}
Over the past many years, investors are running cash into renewable energy, hoping that these investments can ultimately offer a less expensive and a lot of economical supply of energy than this smorgasbord of fuel alternatives. These initiatives are promoted by the general public worry of another atomic energy plant disaster, its venturous waste and therefore the pollution made by fossil fuels. As fossil fuels are consumed to satisfy human wants, they additionally grime the air and water, deface the landscape and destroy the ecological systems. This ends up in unsought sequences like greenhouse emission emission, gas depletion, and air pollution that endanger personalities and every one living creatures. supported all of those problems, the requirement for clean, reliable, abundant, and cheap energy has become evident. Nevertheless, there are some problematic problems with solar power applications; energy isn't on the market in the least times of the day, actually it's principally required at the time it always doesn't exist. the requirement to store this energy for lighting and heating becomes crucial. Energy storage in active heating and cooling systems needs an oversized space, that isn't on the market within the majority of buildings particularly in multi-story buildings. However, PV panels as AN possibility is connected to utility systems; so at the time solar power isn't on the market utility systems will offer the current demanded by the building. therefore grid-connection PV systems in multi-story buildings have to advantages: initial they scale back the requirement for extra area for storage and second, the whole energy demand of the
\end{abstract}

building is glad by the utility at the time once the PV systems don't seem to be able to offer adequate energy. This makes PV systems a a lot of great tool in areas with area restrictions. electrical phenomenon technology makes use of the lush energy of the sun and converts it into current with very little impact on the surroundings. it's usually accepted that PV systems are helpful in tiny buildings and in applications during which there's not that abundant electric power needed. the major unending source is sunlight .solar energy is now utilized in almost every country having an unending source in the best option over another ending source like coal. The study of benefits, as well as impact, has been done in terms of energy savings and indoor environmental qualities. Having an example green roof can be reduced by 55\% of cooling capacity and the green wall can be reduced 10 degrees centigrade indoor temperature and solar energy fulfill $60 \%$ of electricity needs.

Keywords-Photovoltaic cells, climate, energy savings, indoor air quality, aesthetics, design technology, green skyscraper.

\section{I- INTRODUCTION}

$\mathbf{T}_{\mathrm{t}}$ he PV panel idea was initiated once in 1839 a 19year-old French man of science, Edmund Antoine Henri Becquerel, was ready to turn out voltage by illuminating a metal conductor in a very weak solution resolution. nearly forty years later, Adams and Day were the primary to review the electrical phenomenon result in 
solids. They were ready to create cells out of element with one to twenty potency. shortly once this discovery, in 1904, physicist revealed his noted article on the physical phenomenon result. nearly fifteen years later, he won the Nobel prize for his theories explaining the physical phenomenon result. Seven years later, electrical phenomenon technology was born within the North American country once the primary atomic number 14 PV cell with 6 June 1944 potency was created at Bell Laboratories. Early self-made merchandise enclosed PVpowered clam changers and devices that decoded laptop punch cards and tapes. In 1958, Mandelkorn of the North American country Signal Corps Laboratories fictitious crystalline atomic number 14 electrical phenomenon cells. This technology created cells additional immune to radiation and thereby created their use in area exploration more practical. within the Seventies, with facilitate from Exxon Corporation, Berman designed a considerably more cost effective electric cell that brought the value down from $\$ 100$ per watt to $\$ 20$ per watt. This had a serious result on stimulating the PV trade. The complete applications of PV panels began to be thought-about as possible alternatives in remote twelve areas wherever utility-grid connections were too pricy. This event additionally to the growing concern for energy conservation inspired additional analysis and development investments by trade. within the same decade, the world's 1st laboratory dedicated to PV analysis and development, the Institute of Energy Conversion, was established within the University of Delaware with the main focus on thin film electrical phenomenon and star thermal systems. At regarding constant time, RCA Laboratories created the primary amorphous atomic number 14 electrical phenomenon cells, that were more cost-effective to manufacture than crystalline atomic number 14 devices. However, this disadvantage didn't have an effect on the role of star atomic number 14 cells accounting as a dominant technology within the electric cell market. These activities ultimately resulted in launching the alternative energy analysis Institute (today's National Renewable Energy Laboratory), a federal facility dedicated to finding and rising ways that to harness and use energy from the sun. during this decade, NASA's Lewis centre put in a three.5-kilowatt electrical phenomenon system on the Papago reservation in southern Arizona. This became the world's 1st village PV system. It provided power for water pumping and residential electricity in fifteen homes till 1983[1,3]. Due to over urbanization land under vegetation is reduced which is responsible for any adverse effects like climate change, air pollution, overutilization of natural sources which are limited in nature. Therefore there is a strict need for implementation and adoption of various energyconserving and nature conserving methods[4]

\section{II- METHOLOGY}

Photovoltaic cells square measure semiconductor devices that convert solar power directly into electricity. daylight is comprised of photons, or particles of solar power. These photons contain numerous amounts of energy comparable to the various wavelengths of the star spectrum. PV cells respond in the main to light (wavelengths of roughly $450 \mu \mathrm{m}$ to $650 \mu \mathrm{m}$ ). once photons strike a PV cell, a number of them square measure mirrored, some absorbed, and a few might pass during the cell. However, solely the absorbed photons generate electricity. The absorption characteristics of PV cells clearly have an effect on the planning. as an example, traditional glass contains traces of iron. This characteristic causes the glass to retort additional effectively to the visible inexperienced vary. Since PV cells will use this energy, they incorporate low-iron glass. Solar PV systems square measure usually classified into 2 teams, particularly complete systems and grid-connected systems. supported previous arguments, grid-connected or utility-interactive systems seem to be the foremost utilisation for multi-story buildings wherever the obtainable surface is each scarce and pricy. Grid connected solar energy systems offer power to the building whereas connected to the external utility system. Thus, if the demand is over the immediate PV offer, the system attracts the desired supplementary power from the utility grid. If the PV energy is in more than the building demand, then the excess will be sent back to the utility. However, there square measure sure laws that govern the affiliation of PV systems to the utility grid, particularly to beat issues associated with reconciliation the system. Utility corporations in every region confirm these laws and also the buy-back rate of the energy generated by the PV panels[1]. . Green skyscraper having various components are the Green roof, Green wall, Bio-filter, Indoor potting plants. A green roof can the defined as a roof that contains plant or vegetation and it may be fully or partially covered on the roof and its an addition on a normal concrete decked roof. The green roof has several layers the top layer is the vegetation stratum, followed by the growing medium or soil layer, irrigation layer, filter fabric layer, drainage layer, waterproofing membrane layer, and then the roof deck .then Green-wall technologies, are also known as Vertical Greening Systems (VGS) or bio walls. They consist of vertical structures that spread vegetation that may or may not be attached to a building facade or an 
interior wall. On the other hand, species used in outdoor living walls vary greatly depending on location, as well as site-specific microclimate (sun and wind exposure, height, etc.). Traditionally, the green wall has acted as a"passive" Biofilter, but new approaches and technologies are moving towards the integration of living walls (both Indoor and outdoor) air conditioning and ventilation system. In the Green wall, various types of plants are used i.e Spider plant, Dracaena, Ficus, Peace lily, Boston fern, Snake plant, Bamboopalm. Then Biofilter act vegetated return air register. It is a vertical hydroponic green wall containing an arrangement of specifically selected plants. The plants include ferns, mosses, and a range of other flowering and foliage plants. Air is drawn from the green wall of plants and then highly specialized beneficial microbes degrade pollutants in the air into their benign constituents of water and carbon dioxide. The clean air is then distributed throughout the space by a mechanical ventilation system. Then Indoor Air Quality (IAQ)is an international health issue, sincerity dwellers spend $90 \%$ of their time indoors. So, it has become a necessity to improve indoor air quality. Interior landscaping has become increasingly popular During the last 30 years. The main reason for adopting indoor plants is they look attractive, people get attracted by the graceful arch of palm leaves or the exotic beauty of orchids[4]. green skyscraper building constructed the solar photovoltaic cell which having an ampicillin system of solar then components of the solar photovoltaic cell are PV panel, Power. Conditioning Unit (PCU), Inverter, Maximum Power Point Trackers (MPPT), Kilowatt Hour Meter (2way meter), Array DC disconnect, AC breaker panel (fuse), Protection devices[1]

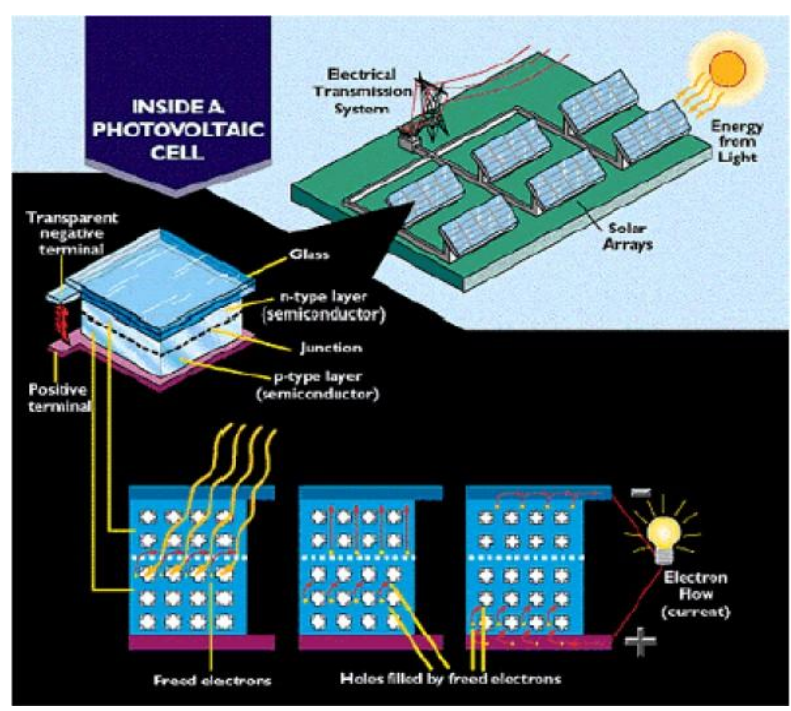

Fig 1- Inside view of photovoltaic cell

\section{III-TYPES OF PHOTOVOLTIC CELLS}

There are completely different types of PV panels which will be interconnected into the building envelope or placed on the roof of the building. supported their thickness, PV panels are often classified into two groups: typical crystalline star cells $(200-500 \mu \mathrm{m}$ thick); and,

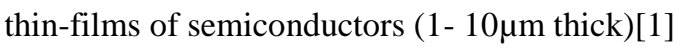

1. Single-Crystal Czochralski (CZ) Silicon: This can be the foremost ordinarily used technique to create a crystal of chemical element from ninety nine percent pure chemical element. during this technique, chemical element is formed into wafers and every wafer undergoes many production steps to become appropriate for business use[1].

2. Ribbon: This can be other technique to grow a ribbon of chemical element out of liquid chemical element. This technique could be a new technique developed by Siemens and it's not utilized in PV production the maximum amount as $\mathrm{CZ}$. the tactic deploys the recycled chemical element from former semiconductor devices and reshapes it to new crystalline chemical element. thirty Some cells ar specially designed to work with focused daylight, whereas others ar utilized in nonconcentrating flat-plate systems. Concentrators ar lenses or reflectors that focus daylight onto the cell modules. However, Concentrating PV (CPV) is that the least mature technology in reference to megawatts readying and continues to be terribly pricey[1].

3. Multi-crystalline: During this technique, the chemical element soften is cooled terribly slowly below controlled conditions. The cell contains comparatively giant areas of single crystalline grains, every on the order of one $(\mathrm{mm})$ to ten $(\mathrm{cm})$ in size. though this technology yields comparatively cheap merchandise, its potency is a smaller amount than single crystalline technology $(11-15 \%)$. This technology is particularly widespread in Europe[1].

4. chemical element crystallinecells These are often laminated in layers of fabric that provide structural support and weather protection. The higher level is tempered glass. successive layers ar made from ethelyn vinyl acetate (EVA) that encapsulate the cells. The last layer could be a sheet of compound to stop wet penetration. The last layer can even be a glass sheet, that is additional appropriate within the BIPV application.[1].

\section{IV-FUNCTIONAL REQUIREMENTS}

One of the elemental steps in coming up with a system is associate degree initial practicableness study, during 
which designers judge all the aspects of the look. This includes website analysis, shading and radiation studies, system engineering configuration, instrumentation integration, and of all the problems related to installation and system integration. it's additional economical to assess PV panels within the preliminary style stage. PV array single-line diagrams and computer-aided shading and radiation studies area unit necessary for PV styles. However, these criteria, together with the intrinsic characteristics of PV panels, limit PV operational opportunities as a primary energy supply in these sorts of buildings; thus, they can't satisfy the building's power desires and may be put in together with backup power (i.e., the external utility grid or different energy sources). However, it ought to be noted that the study model may be a subjective one hundred and one model, and also the results could modification dramatically by dynamic variables that have an effect on PV panel performance, like shading and temperature[1].

\section{V-ECONOMIC DEVELOPMENT}

Although it's assumed that it's potential to control PV panels anyplace radiation exists, in some areas it's not economically viable. The geographical area determines not solely the quantity of sunshine however conjointly the value of grid provided electricity. The practicability study given here considers the social science of engineering, material, installation prices, and also the quality of the project. withal, another variable is whether or not existing tax incentives square measure favorable to 102 renewable energy sources like PV. Yet, the terribly high initial prices of PV panels create them associate degree unattractive various for building designers despite the fact that life-cycle analyses show some quantity of saving over the entire life of the PV project. associate degree integrated building energy system is usually procured through a construction budget. Electricity generated by the BIPV grid creates savings that scale back operational budgets. However, most multi-story workplace buildings square measure chartered by their occupants; the owner of the building doesn't essentially occupy the building. Therefore, life cycle analyses of savings on electricity square measure a compelling issue for occupants, United Nations agency buy power consumption, however these savings don't essentially interest building house owners[1].

\section{VI-CONCLUSION}

As above we can conclude that the photovoltaic cells can be effectively used in modern skyscrapers and with its effective use we can also see the positive outcome towards energy utilization. From the above study we can clearly say that solar energy can be used for electricity generation and with the help of solar energy we can overcome the utilization of nonrenewable sources. This technology will play a very important role in energy conservation and in future also we can utilize or harness this energy. For growing cities in modern skyscraper building should be constructed for increasing the planting as well as environmental pollution should be controlled.

\section{REFERENCES}

[1] Application of PV Panels in Large Multi-Story Buildings. A Project Report Presented to the Faculty of Architecture California Polytechnic State University San Luis Obispo. In Partial Fulfillment of the Requirements for the Degree Master of Science in Architecture by Sara Kayal June 2009

[2] Energy-efficient building design in the context of building life cycle Izzet yuksek, tulay tikansak karadayi march 2016 open access peer-reviewed chapter DOI: $10.5772 / 66670$

[3] Farzad Navami. An Overview of Sustainable Design Factors in High-Rise Buildings. International Journal of Science, Technology and Society. Special Issue: Research and Practice in Architecture and Urban Studies in Developing Countries. Vol. 3, No. 2-1, 2015, pp. 18-23

[4] Shahrina Afrin .Green skyscraper: Integration of plants into skyscarpers.degree Project SoM EX 2009-35 ,Stockholm 2009 ,KTH, Department of Urban Planning and Environment Division of Urban and Regional Studies Kungliga Tekniska högskolan www.infra.kth.se/sb/s 